\title{
Bone Fractures and Analgesia: Figures from the Orthopedic Emergency
}

\author{
Ashique Ali Arain ${ }^{1 *}$, Syed Muhammad Ali ${ }^{2}$ and Mohammad Hasnain Khanzada ${ }^{2}$ \\ ${ }^{1}$ Department of Pharmacology, Isra University Hyderabad, Pakistan \\ ${ }^{2}$ Department of Orthopedics, Liaquat University of Medical and Health Sciences, Pakistan
}

Submission: December 14, 2017; Published: January 12, 2018

*Corresponding author: Ashique Ali Arain, Consultant Family Physician and Assistant Professor, Department Of Pharmacology, Isra University Hyderabad, Sindh, Pakistan, Tel: 00923333389250; Email: ashiquepcmd77@yahoo.com

\section{Abstract}

Introduction: Accidental injuries are part of human life and present in a variety of styles ranging from soft tissue damage to complexed bone fractures. We observed the emergency presentations of the orthopedic patients with different body part injuries. The nature of injury and associated damage was assessed by clinical and radiological tools. Analgesia and fracture management was done according to nature of trauma using general and local anesthesia as needed.

Methodology: Both genders presenting with any sort of trauma at any age were included and non-traumatic non orthopedic emergencies were excluded. Centre for study was liaquat university of medical and health sciences orthopedic section of the emergency department. X-rays were obtained for ruling out fractures and soft tissue injuries. Name, age, gender and other biodata were collected from patients or attendants as found convenient. Sample size was taken 99 and sampling technique was non probability, purposive sampling.

Data Analysis: information received from subjects was analyzed in terms of frequency, percentage, mean age was also calculated.

Results: A figure of $42(42.42 \%)$ was found with bony fracture while $57(57.5 \%)$ had no bone injury. $16(16.16 \%)$ were female $04(4.04 \%)$ out of them had fractures while $12(12.12 \%)$ were having soft tissue injuries, $83(83.83 \%)$ were male $38(38.38 \%)$ had fractures while $45(45.45 \%)$ had their bones saved. NSAIDs were mostly used analgesics with tramadol as alternative other techniques were not in common practice here.

Conclusion: Male were the predominant subjects to trauma and the same gender was more prone to have bone fractures as compared to female with lower limb at more risk and NSAIDs still remain the first choice as analgesia.

Keywords: Bone fractures; Soft tissue injuries; Anesthesia; Analgesia

\section{Introduction}

Bones are the pillars of the building of the human body giving a beautiful structure to what would have been a heave of flash. The commonest reason for morbidity and mortality in pediatric, adults, men and women population is trauma. Fractures place strong impact over the society along with the patients and their families through utilizing financial and human resources. All age groups are commonly affected by these mishaps trauma being a commonest factor responsible for morbidity as well as mortality in children second to acute infections [1]. The prevalence of femoral fractures in children was declared 2\% in mid 90s (1994) [2]. The young population is more prone to femoral fractures (neck-shaft) owing to over speeding accidents along with height falls.

The incidence is between $2.5 \%$ to $9 \%$ for the femoral neckshaft fracture of the same side and the same is increasing with time [3-5]. Osteonecrosis of femoral head, acomplication of femoral neck fracture can be reduced with early fixation that also enhances the union chances [6]. Distal tibial Pilon fracture accounts for $3 \%-10 \%$ of tibial fractures and $1 \%$ of all fractures of lower limb with a ranging $11.4 \%-54 \%$ complication rate [7]. Pilon fracture are characterized by severe soft tissue injuries, articular cartilage damage and metaphyseal compression resulting from axial load and shear stress due to sports or traffic accidents [8-10]. Distal radius fractures were thought to be $1 / 6$ of the total fractures presenting to the emergency and it was considered as the fracture of elderly but now a day's all age groups are seen to be affected. Elderly people are at more risk of fractures due to osteoporosis, reduced BMD, menopause [11].

About 2 million fractures occurs in united states due to osteoporosis annually consuming 17 billion dollars specially in elderly postmenopausal women and the incidence of the same is supposed to rise three times by 2040 [12]. Symptomatic 
arthritis of posttraumatic origin occurs following a healing with more than $2 \mathrm{~mm}$ articular congruity after intra-articular radius fractures [13]. Road traffic crash (RTC) is one of the main causes of injury responsible for approximately 50 million injuries, per year, worldwide [14]. Pain is the predominant complaint of emergency room trauma patients and its management is a challenge with reported low patient satisfaction [15]. NSAIDs (Celecoxib, Rofecoxib Ibuprofen, Diclofenac, Ketoprofen, Flurbiprofen), Opioids analgesics (Morphine, Codeine, Methadone, Pethidine, tramadol) and ketamine (a dissociative anesthetic) are the recommended drugs for moderate to severe pain along with the regional block and all are successful treatment options for analgesia $[15,16]$. The present survey was planned to evaluate the frequency and percentage of bone fractures in patients presenting to the orthopedic emergency with the history of trauma and the preferred use of analgesics and their routes of administration.

\section{Methodology}

Patients visiting the orthopedic emergency were evaluated for required parameters and biodata was collected. Patients with age range $>5$ years, having history of trauma by fall or accident were included in the survey through non probability, purposive sampling. Patients with chronic previously operated fractures, fracture of skull and thoracic trauma requiring ICU set were also excluded.

\section{Data Analysis}

Frequency and percentage was calculated for gender, fracture and soft tissue injuries and presented in table and charts.

\section{Results}

Male and female were $83.83 \%$ and $16.16 \%$ respectively $42.42 \%$ were found to have fractures while 57.57 were no fracture soft tissue injuries. Majority of fractures belonged to lower limb 25(59.52\%) with 10(40\%) Tibia, Fibula and 9(36\%) knee joint while $17(40.47 \%)$ were associated to upper limb with top most $7(28 \%)$ carpel and metacarpal. All cases (100\%) received analgesic medicines majority of them were given diclofenac sodium while a small proportion required opioid analgesic tramadol (Table 1) (Figures 1-3).

Table 1: Case distribution according to gender.

\begin{tabular}{|c|c|c|c|}
\hline Parameter & Male & Female & Total \\
\hline Fractures & $38(38.38 \%)$ & $04(4.04 \%)$ & $42(42.42 \%)$ \\
\hline No Fractures & $45(45.45 \%)$ & $12(12.12 \%)$ & $57(57.5 \%)$ \\
\hline & $83(83.83 \%)$ & $16(16.16 \%)$ & $99(100 \%)$ \\
\hline
\end{tabular}

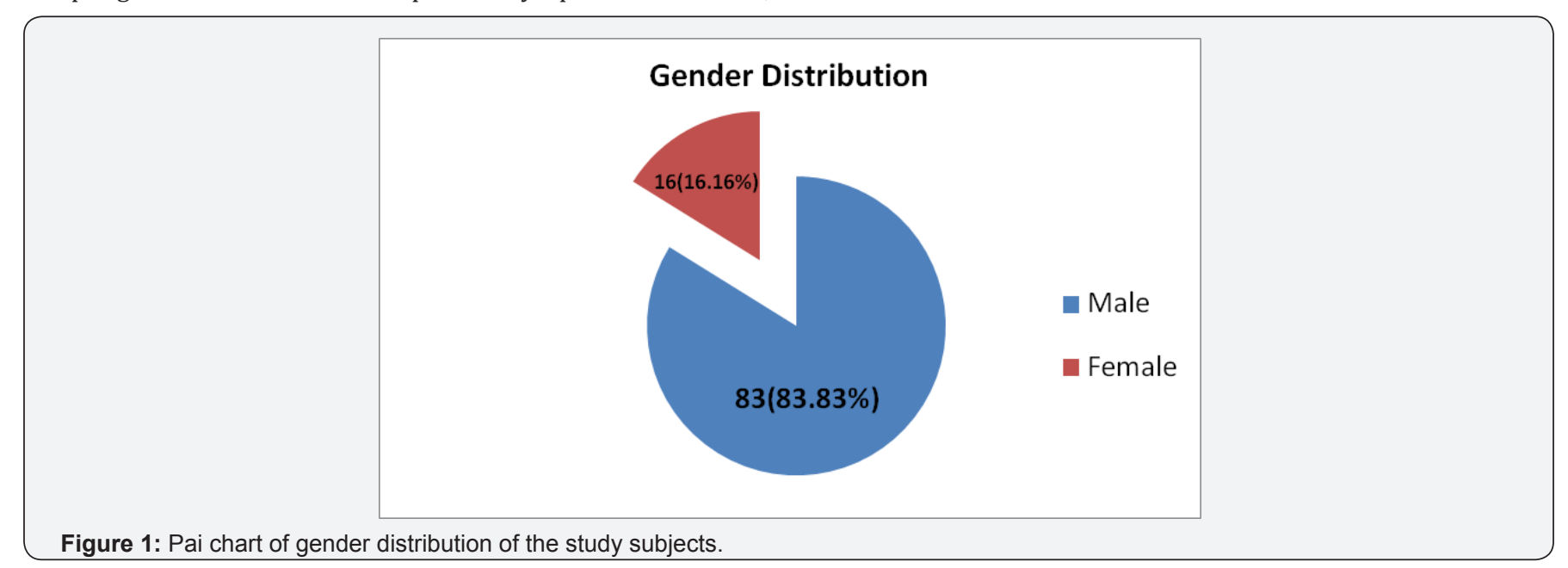

Figure 1: Pai chart of gender distribution of the study subjects.

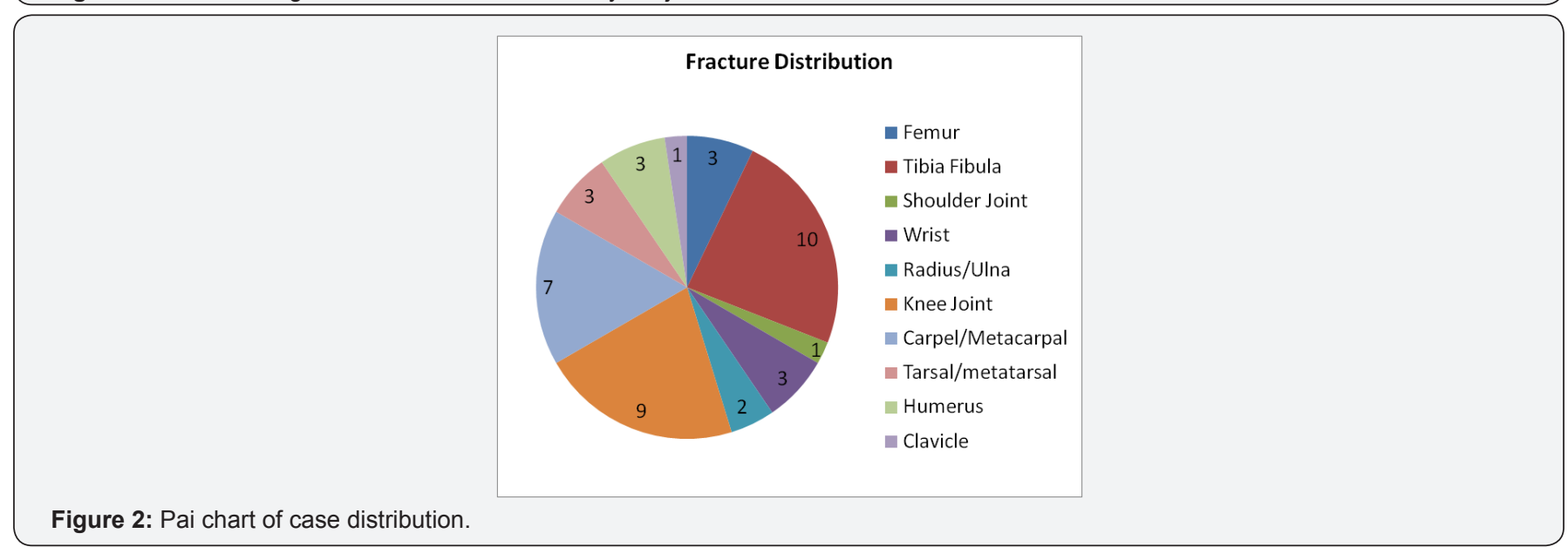




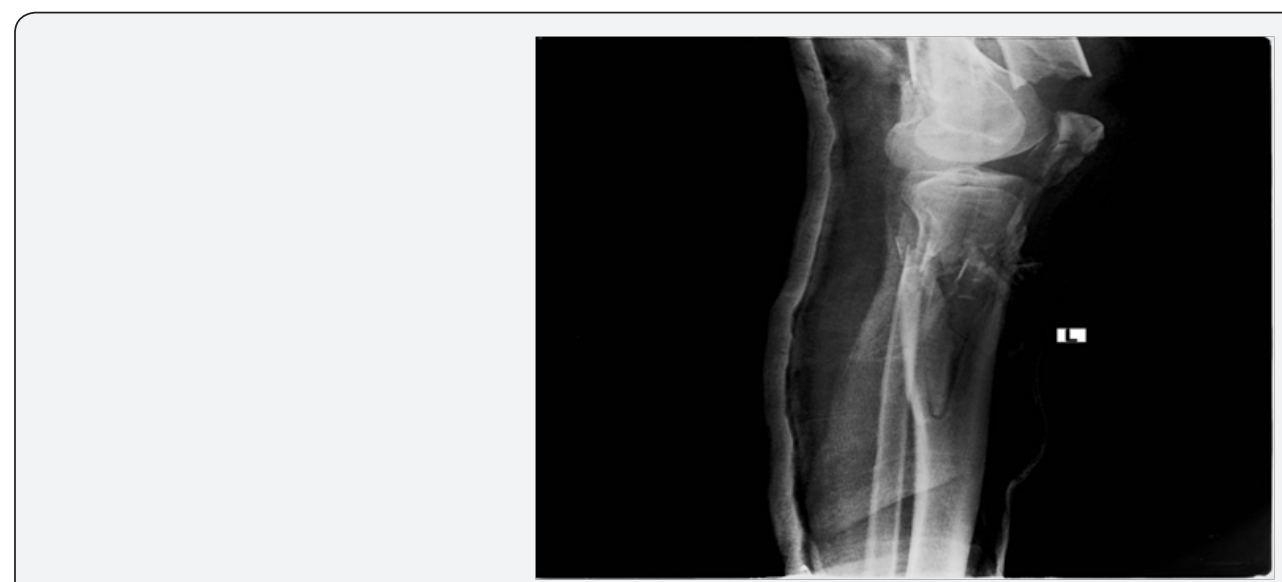

Figure 3: A worst type of the fracture floating knee with more compound fracture of the tibia.

\section{Discussion}

\section{Fractures of the Lower Limb}

Soft tissue with poor circulation and high risk of different complications make Pilon fracture difficult to treat with a poor prognosis. Its previously used surgical therapies include open reduction and internal fixation (ORIF) and external fixation (Open fractures) combined with limited internal fixation (closed fractures). Proximal or distal tibial fractures are treated with butter's plate while shaft fractures are handled by interlocking nails used. In past, these fractures have been treated through different modalities. Historically these fractures were managed conservatively in cast by applying hip spica, which in return produces acceptable results [4]. Such method of treatment produces too much physical and mental stress on patient and his/her family [5]. Femur neck fractures need cancellous screws but in IT (Intertrochanteric) fractures we use DHS (Dynamic hip screws) and DCS (Dynamic compression screw). While in open fractures we use external fixator Titanium elastic nailing (TEN) has gained popularity over the last two decades and is now being most widely performed procedure for femur shaft fractures in children aged 6 and above [6]. Elastic intramedullary nailing provide stable fixation and allow rapid postoperative functional recovery in 6-10 years of age group [17]. Current study found majority of fractures of tibia and fibula that is consistent to previous reports [18].

\section{Fractures of the Upper Limb}

Neck fractures are managed with K-Wires (Stable fractures I, II), Head replacement (Type IV) according to neer's classification while shaft with Interlocking nails (recommended) but most of the surgeons use plating as the bones are thinner and the medullary cavity is narrow however external fixator in case of open wound. Wrist fractures are best handled by plating of butters T and L shape but if the bone quality is poor LCDCP (Low contact dynamic compression plates) is suggested. For clavicle conservative therapy is the best but recon plate may also be used. Our results did not found accordance with Billy T.H 2011 who showed majority of the fractures probably due to sample size difference that was 250 for his study [18].

\section{Analgesia}

Our study showed the majority of the patients were given NSAIDs and opioids were rarely used where the pain was not tolerable. Most frequently used NSAID was diclofenac Sodium while tramadol was the available alternative for severe pain. Our results were consistent with Belli TH et al. [18] who also reported diclofenac sodium to be most commonly used analgesic how he did not reported any opioid use [18]. NSAIDs mediate their analgesic effects through reducing the synthesis of prostaglandins [19]. Opioids have multiple mechanisms including substance $\mathrm{P}$ and $\mathrm{u}$ receptors reducing the pain perception as well as increasing the pain threshold at the levels of spinal cord with best use in intense pain parentral [20].

\section{Conclusion}

Male were more affected by fractures in comparison to females, lower limb injuries were higher then the upper limb, NSAIDs were the most commonly used analgesics, parentral route was the most effective one in emergency settings.

\section{Recommendations}

1. Safety measures need to be incorporated in the system specially for limb protection.

2. Teenagers trend of driving in our cultures needs to be controlled by law and public awareness

3. Over speeding inside the cities should be penalized high

4. Analgesic use need more evaluation and addressing regarding comparison between opioid and NSAIDs in many aspects like early analgesia with low side effect profile

\section{References}

1. Steel N Reading R (2002) Epidemiology of childhood mortality. Current Paediatrics 12(2): 151-156.

2. McCartney D, Hinton A, Heinrich SD (1994) Operative stabilization of pediatric femur fractures. The Orthopedic clinics of North America 25(4): 635-650.

3. Raviraj A, Anand A (2011) Ipsilateral femoral neck and trochanter fracture. Indian journal of orthopaedics. 45(3): 284-285. 
4. Watson JT, Moed BR (2002) Ipsilateral femoral neck and shaft fractures: complications and their treatment. Clin Orthop Relat 399: 78-86.

5. Jain P, Maini L, Mishra P, Upadhyay A, Agarwal A (2004) Cephalomedullary interlocked nail for ipsilateral hip and femoral shaft fractures. Injury 35(10): 1031-1038.

6. Boulton CL, Pollak AN (2015) Special topic: Ipsilateral femoral neck and shaft fractures-Does evidence give us the answer? Injury 46(3): 478-483.

7. Guo Y, Tong L, Li S, Liu Z (2015) External fixation combined with lim $\neg$ ited internal fixation versus open reduction internal fixation for Treating Ruedi-Allgower type III Pilon Fractures. Med Sci Monit 21: 1662-1667.

8. Schweigkofler U, Benner S, Hoffmann R (2015) Pilon fractures. Z Orthop Unfall 153(3): 335-354.

9. Klaue K, Cronier P (2015) Pilon fractures. Unfall chirurg 118(9): 795801

10. Boraiah S, Kemp TJ, Erwteman A, Lucas PA, Asprinio DE (2010) Outcome following open reduction and internal fixation of open pilon fractures. J Bone Joint Surg Am 92(2): 346-352.

11. Furquan QM, Solangi NA, Chachar MB, Khamisani GM, Ahmed MW, et al. (2015) Intra-articular distal radius fractures; functional outcomes of percutaneous kirschner wire fixation and short arm cast in patients of 20-70 years. Professional MedJ 22(7): 944-948.

12. Sayed-Noor, Kadum BK, Sjödén GO (2010) Bisphosphonate-induced femoral fragility fractures: What do we know? Orthopedic Research and Reviews 2: 27-34.
13. Haus BM, Jupiter JB (2009) Intera-articular fractures of the distal end of the radius in young adults: reexamined as evidence based outcome medicine. J Bone Joint Surg Am 91(12): 2984-2891.

14. Peden M, Scurfield R, Sleet D, Mohan D, Hyder A, Jarawan E, et al (2004) World report on road traffic injury prevention. World Health Organization, Geneva, Switzerland.

15. Ahmadi A, Bazargan-Hejazi S, Heidari Zadie Z, Euasobhon P, Ketumarn P, et al. (2016) Pain management in trauma: A review study. J Inj Violence Res. 8(2): 89-98.

16. Stephen H Thomas (2013) Management of Pain in the Emergency Department. ISRN Emergency Medicine. 583132: 19

17. Syed Kamran Ali Shah, Asif Peracha, Muhammad Arsalan Ghazi, Nouman Memon, Kazim Rahim Najjad, et al. (2017) Role of Elastic Intramedullary Nail for the Treatment of Femur Shaft Fractures in Children. JOPA 29(2): 35-39.

18. Haonga BT, Makupa JE, Muhina RI, Nungu KS (2011) Pain management among adult patients with fractures of long bones at Muhimbili. Tanzania Journal of Health Research 13(4): 107-111.

19. Robin Moorman Li (2013) Opioids. Lippincott Illustrated Reviews by Kren Whalen ( $6^{\text {th }}$ edn), pp. 191-204.

20. Daniel E Furst, Robert W Ulrich, Shraddha P (2012) Nonsteroidal Anti-inflammatory Drugs, Disease -Modifying Antirheumatic Drugs, Non Opioid analgesics and drugs used in gout. In basic and clinical pharmacology (12 $2^{\text {th }}$ edn), pp. 635-657.

\section{Your next submission with Juniper Publishers} will reach you the below assets

- Quality Editorial service

- Swift Peer Review

- Reprints availability

- E-prints Service

- Manuscript Podcast for convenient understanding

- Global attainment for your research

- Manuscript accessibility in different formats

( Pdf, E-pub, Full Text, Audio)

- Unceasing customer service

Track the below URL for one-step submission https://juniperpublishers.com/online-submission.php 